\title{
Community Foundations - A Model for Slovenia?
}

\author{
TOMAŽ KLENOVŠEK
}

\begin{abstract}
Community foundations represent a relatively new form of foundations. The primary goal of community foundations is to improve the quality of life for those living in a closed area, usually in a city or region. The concept has its roots in the USA where community foundations have a long and successful history. After all, due to the amounts of funds spent on public purposes, they are also very important factors in shaping the public life. Then the paper presents the basic characteristics of community foundations. After describing the first community foundation, established in Gütersloh, Germany, a thought has been given to advantages of community foundations and to their potentials for the circumstances in Slovenia.
\end{abstract}

KEYWORDS: • foundations $\bullet$ community foundations $\bullet$ civil society

- Slovenia 


\section{Introduction}

Community foundations ("Bürgerstiftungen") represent a modern organisational form for achieving generally beneficial objectives. The simplest definition would read that it is about the constitution of a "member community that works for the community". In literature and in practice there is considerable consent regarding its main characteristics which are: autonomy and independence; it works for generally beneficial purposes to realise a wide range of objectives in a geographically rounded (local or regional) area so that the foundation's assets are gradually accumulated; and it works so that the organisational structure, asset management and distribution of funds are totally transparent.

The model comes from the US where Frederick H. Goff, a well-known lawyer and banker, established the first foundation of this kind in Cleveland as early as 1914. Goff came to the idea to combine multiple trusts ${ }^{1}$ into one single foundation where he pursued two objectives. On the one hand, he wanted to offer the less wealthy fellow citizens the possibility of pooling their resources and voluntary work to realise the generally beneficial objectives. On the other hand, he was looking for the way how to ensure that the foundation could operate also in the changed social conditions and facing new needs (Walkenhorst, 2004).

In the next decades, the concept greatly extended to all the US, initially in the Middle West and North West. Important effects for further development were brought particularly by the tax reform in the seventies. It put the community foundations to a more favourable position vis-à-vis private foundations (Sacks, 2004:40).

In this respect, it needs to be noted that in the US even today there is still a strong culture of philanthropy, i.e., the practice of contributing private funds for the general benefit ${ }^{3}$.

Community foundations represent one of the fastest-growing segments of foundations in the US today because currently, there are about 600 such foundations (according to information of Transatlantic Community Foundations Network - TCFN) with total assets of US \$ 31 billion, and they are among the most important players in the American public life.

Thanks to its exceptional performance and innovativeness, this concept has also established itself in many other countries. So, in Canada today there are already 80 community foundations that allocate more than CAN \$ 50 million for charitable purposes per year. In Great Britain there have been over 40 such foundations established during the last few years. And Great Britain is the first European country where the community foundations have established themselves. In the recent past, there have been the first such foundations set up also in the South African Republic, Italy, Poland, Bulgaria, Slovakia, ${ }^{4}$ the Czech Republic, and in 
Germany where this concept has especially come to life. Since the first community foundation in 1996, there have been around 80 such foundations established so far (according to the Maecenata Institute information, 2005). Last but not least, the presence of the community foundations in Germany is proved by the fact that there are even five support organisations ${ }^{5}$ that offer assistance in establishing the foundations and in giving them substantial guidelines. The local experiment, which commenced in Ohio nearly a hundred years ago, represents now an internationally successful model for the philanthropic involvement at the local level.

\section{The Basic Characteristics of Community Foundations}

In order to better understand the community foundation concept, here is a more detailed description of its main characteristics as defined by the Community Foundations Working Group at the Association of German Foundations ${ }^{6}$.

A community foundation is defined as "an independent, autonomouslyfunctioning, generally beneficial foundation founded by the members of a community for the well-being of this community, and for the widest sphere of activity. It is established to be permanently active for the well-being of a community in a geographically rounded area. As a rule, it performs both the support and operational tasks for the residents from its hinterland. By doing its work, it supports civil engagement activities" (Bundesverband Deutscher Stiftungen, 2000:1).

In addition to the definition itself, the document above specifies 10 basic characteristics that largely clarify the main features of this specific form of foundations:

1. A community foundation is generally beneficial and it wants to strengthen the community as such. It needs to be considered as a selfdeciding part of the civil society.

In its first meaning, the community foundation is a foundation, though, of course, with its peculiarities. In substance, however, it pursues the objectives because of which the foundations have been established. Foundations represent an institute with an exceptionally long history. According to some data, its beginnings go back to ancient Greece. However, it cannot be ignored that the role and importance of foundations have changed throughout the history (Smith; Borgmann, 2001). The two authors therefore conclude that the historical analysis can contribute to an overall outlook on the foundations today. Firstly, they suggest that it is reasonable to see foundations more as adaptable structures, which are capable to operate in different environments, rather than as purely legal entities. Therefore, in order to survive regardless of 
time and space, the foundations must have the ability to adapt. The general or public benefit is never seen as something static, and the boundary between the public and private sector has been constantly changing throughout the history. That is why they suggest seeing the foundations as a flexible instrument for achieving general benefits. Furthermore, they should be seen as a tool for redefinition of the public objective and for resetting the boundaries between the civil society, Government and the market (Smith; Borgmann, 2001:31). Secondly, they also indicate that attention needs to be paid to the changing philanthropic motives, objectives and strategies. Throughout the history, the foundations have been built on the basis of very diverse objectives: to be given public honour, to set up a monument due to godly fear and salvation, for reasons of public order or social control, due to scientific progress or class consciousness, and, of course, last but not least, because of altruism, noble-mindedness and generosity. Through examining the donors' intentions, it can be understood why the foundations have survived until today, although they disappeared for some decades due to political circumstances in some parts of Europe after the Second World War. Thirdly, Smith and Borgmann suggest seeing the foundations in a political or constitutional context. Irrespective of the wealth they hold, the foundations are basically dependent institutions that depend on the legal regulation and welfare created by the developed economic sector.

2. As a rule, a community foundation is established by several founders. The initiative for its establishment can come from individuals and from individual institutions.

Unlike most traditional foundations, where the number of founders is small or the founder is one single, the community foundations are established so that, as a rule, several founders (coming from different spheres of social life) merge. In an ideal case, partners are: from the local self-government, regional business entities and individuals with large or small stakes.

3. The community foundation is economically and politically independent. It is not bound by any religion and party-political line. It rejects the dominance of individual founders, parties or companies. Political committees or management boards must not have a decisive influence on decision-making.

Independence represents one of the key features of the community foundations, which is partially linked to the preceding feature. Since the community foundation is from the residents for the residents, it tends towards versatile independence from its founders. The primary tasks of the founders are: to collect funds for the work of the foundation, to draw 
up its statute, and to determine its mission or areas of activity. Although these foundations, as a rule, perform service and maintenance functions for their founders, the foundation management is carried out by the Management Board made up of adequate and qualified people from the geographical area in which the foundation operates (Strachwitz, 2004:132).

4. The area where the community foundation performs its activities is a certain geographic whole: town, district or region.

In practice, the question always arises what the appropriate geographic unit is for the operation of community foundations. Foreign experience suggests that the key issue is in what area a sense of belongingness can be created. There are well-known cases that the foundation operation area can extend from a few thousand up to several hundred thousand residents (Sacks, 2004). In the case of Slovenia, a community foundation could operate in the area of a small town (e.g., Slovenske Konjice), in the area of a large town (e.g., Maribor), or in the area of the entire Podravje Region.

5. The community foundation gradually builds its capital base. In so doing, it offers all the residents (who feel to be linked to a specific town or region and who agree with the objectives of the foundation) the possibility to contribute their funds. In addition, it also collects contributions for precisely defined projects, and it may establish subfoundations and funds that pursue individual objectives from the statute, or they just support part of the regional area.

Flexibility as one of the main features of the community foundations is reflected in this characteristic. Due to the necessary independence and the desire to be involved in the life in the local environment, community foundations try to attract a larger number of (co)founders. Community foundations build their assets gradually through the interests, dreams and visions of their founders (Monroe, 2004:213).

6. The community foundation has a broad spectrum of activity in the life of the town or region the development of which is the real purpose of its existence. The application domain of the foundation is therefore very broad. As a rule, it covers the cultural sector, youth and social welfare, education, nature, environment and monuments protection. There can be grant-making and operating foundations. They certainly tend to be innovative.

Different classifications of classes often appear in literature (Trstenjak, 1997, Anheier, 2001). Dividing foundations into grant-making and 
operating foundations $^{8}$ is relevant to our needs. Also in this regard, community foundations are a peculiarity because these two predominant modes of operation are most frequently combined in practice.

7. The community foundation supports the projects based on civil engagement, or provides assistance in self-help. In doing so, it advocates for new forms of social involvement.

It must not be overlooked that the community foundations represent a very innovative form of civil and social involvement. In the past few decades, this type of foundations has established itself in the world for the very reason that despite all the local and regional differences, the belief has established itself that a democratic society largely depends on the active involvement of its citizens (Walkenhorst, 2004:13). Thanks to its independence and autonomy, it represents a remarkable catalyst of a civil and social involvement. There is hardly any other institution that is able to support a variety of beneficial activities, to deal with the burning social issues in the community, or merely to enhance the quality of life in a certain area.

8. The community foundation projects are public. By having intense contacts with the public, the foundation wants to enable all the residents of a town or region to join the projects.

From residents for residents principle is reflected also in this characteristic. The community foundation can fully come to life and can find a long-term support in a given environment only if the residents take it for theirs. Due to their very broad orientation, area of work, and their wish for the residents to participate as much as possible (either in the form of funds or voluntary work), in this respect, the community foundations greatly differ from traditional foundations.

9. A community foundation could coordinate the local network of different charitable organisations in a given town or region.

Being an independent and neutral institution supporting the community, the community foundation can act as an intermediary, movement integrator, or as a catalyst for the implementation of some ideas. The practice from different countries has shown that jointly with other organisations, community foundations (Sacks, 2004) carry out various projects or they do that for other organisations; they establish partnerships between public and private services, and they draw the national and international donors' attention to local projects. 
10. The community foundation's internal work is characterized by participation and transparency. The community foundation has several boards (management board and control bodies) in which residents perform operational and control tasks for residents.

In all respects, community foundations operate publicly and transparently. Therefore, the public, founders and donors are regularly informed about their objectives, activities, financial condition, the use of resources and about the organisational structure. This feature is particularly important ${ }^{9}$ in a period when the credibility of some important non-governmental organisations (e.g., Red Cross) is affected because of various scandals that have been associated with the phenomena of corruption.

\section{The Establishment and Legal Regulation}

Community foundations represent an organisational form that combines in itself some fundamental characteristics of both societies and foundations. According to Strachwitz (2004:127), it can be said about the latter that it is about the two complementary organisational forms for civil social activity. Although both forms have a long tradition, they follow various fundamental principles. On the one hand, a society represents such an organisational form where the democratic principle of participation has to be implemented time and time again in practice because of the voluntary members, but on the other hand, a foundation follows the principle bound by the statute that was drawn up upon the establishment of the foundation. So, if the foundation depends on the stability in implementing the initially outlined task, the societies are subject to the continuous process of forming the volition.

The basic principles of both these forms are reflected in the community foundations. The community foundation is basically the right foundation (universitas bonorum), but with its organisational form for civil social activity, it tries to follow the basic democratic principles in its internal organisation.

Since the positive legal regulation is very different in individual countries where the community foundations operate, that is to say, not only in the countries belonging to the Anglo-American legal system and to the continental legal system (for more details, see Trstenjak, 1997), but also in the regulations within each system (see, for example, Schlüter, Then, Walkenhorst, 2001), the mere rough presentation of them would much exceed the purpose of this paper. Therefore, the main dilemmas will be described this time, or the fundamental issues will be presented to be solved by the initiators upon establishing the foundation itself ${ }^{10}$. 


\subsection{Legal form}

Various legal orders are familiar with the distinction between the foundation for which the law recognizes the legal person characteristics (e.g., rechtsfähige Stiftung in Germany) and the foundation that has no such characteristics (nicht rechtsfähige Stiftung). However, it is about academic distinction because in the countries with the continental legal system there are, as a rule, foundations with the legal person characteristics. So, they are also subject to the state's control. ${ }^{11}$

The issue of decision-making regarding the legal form in which the community foundation is to be established is more relevant to our needs. Judging by foreign experience, the very form of the foundation ${ }^{12}$ is important when establishing the community foundation. The legislation of the European countries is fairly varied in regulating the issue of foundations (Schlüter, Then, Walkenhorst). In our case (the Foundations Act, Official Journal No. 60/95), the foundation is necessarily the private law person. In a way, this fact is good, because if the community foundation were established by different partners (local bodies, business entities, non-governmental organisations), it would remain more independent than if it had a status of the public foundation in which political influence might become evident to a larger extent.

\subsection{Name}

To select the foundation name is usually not very difficult. The name is made up of the words »community foundation « and the name of the town, district or region to which it refers.

\subsection{Place of establishment}

As a rule, the seat of the foundation will be there where it will operate. This will usually be a town or region. If the foundation covers a wider area, the seat will have to be determined by using certain pragmatic criteria (the place where the foundation activities will be mainly performed, where the head office / management will be, etc.).

\subsection{Assets}

Upon establishment, each community foundation must have assets. The foundation does not have to have financial resources because any assets can be taken into account, for example, real estate, interests in companies, certain entitlements, and also works of art. In this regard, another important issue is asset management and tax legislation in terms of tax benefits for (co)founders and donors. 


\subsection{Objective}

One of the fundamental principles of the statute dictates that the objective and assets of the foundation should be in a reasonable ratio (Walkenhorst, 2004). In the case of the community foundations, this principle is slightly more difficult to implement because during the time of the existence of the foundation, the assets are gradually increasing, whereas the objective needs to be determined upon the establishment of the foundation. In practice, it is not reasonable to enter excessively numerous objectives into the statute because this might cause problems with the registration, especially if all the objectives are not generally beneficial. On the other hand, this might deter future (co)founders or donors. Finally, the definition of the objective for the foundation is the most remarkable and important task of the founders. So, these important formulations must not be watered down by using any flowery language (Strachwitz, 2004:141).

It is usually most reasonable to choose a few superior words, such as the promotion of giving help to the young, the promotion of culture, etc.., and then, these areas are to be specified in more detail, e.g., the traditional culture is to be especially promoted, etc. Such formulations allow later modifications due to possible changed conditions in the foundation operation.

\subsection{Organisation}

The organisational structure must be determined by the founders upon the establishment of the foundation. However, also in this area, the main differences can be noticed between the community foundations and the traditional foundations. If the latter are usually based on the volition of one single founder, the essence of the community foundations lies in the fact that new and new founders always come up (Strachwitz, 2004), although they have to be formally subordinated to the existing statute. Despite all that, they have certain possibilities of influencing (e.g., at the founders' meeting, etc.).

The constitution of the community foundation bodies can be very diverse. Within the foundation there are various committees (e.g., project evaluation committee), boards (e.g., supervisory board) and assembly.

In practice, the range of competences includes: the right to share in decisionmaking about the composition of the foundation management, the right of reservations in the management decisions. Further variants are possible in implementing the rights of participation in the assembly of the foundation, etc. 


\section{An Example of the Community Foundation: Stadt Stiftung Gütersloh}

In order to illustrate the starting points presented above, let us have a closer look at how the establishment of the first community foundation took place in Germany. It is about the Stadt Stiftung Gütersloh community foundation, founded in 1996 (summarized according to Spallek, 2004).

The main purpose of establishing the community foundation of the town Gütersloh was to enhance the quality of life, to make the basis for social problem solving, and to support civil involvement in this town because it is not enough to merely draw the residents' attention to their responsibility towards their community, but they must be given an opportunity to actively participate in carrying out tasks.

Thanks to its financial and political independence, the community foundation has different options for achieving the objectives defined in the statute: on the one hand, it can start new projects and thereby getting the various actors around the same table to intervene between them or to assist them in finding the basis for appropriate solutions. But on the other hand, it supports a variety of activities of other beneficial foundations which have, through their work, proved that they do useful work. Support can be of financial, intermediary or advisory nature. It is usually reflected in the following forms:

\section{- $\quad$ Support project work $^{13}$}

This form represents financial support to the projects of other generally beneficial societies or civil initiatives, provided, of course, that these projects are in accordance with the statutory defined objectives of the community foundation. In this case, the foundation makes available its resources for the implementation of these projects. The support project work objective is to support the already existing capacities for civil or social involvement.

\section{- Combined operative and supportive work $^{14}$}

It frequently occurs that the participation in operational projects, namely, in those provided by the community foundation along with other foundations, leads to long-term financial support. These cases most frequently occur when the community foundation looks for long-term partners to implement certain projects which it has (co)established, but it must ensure medium-term financing until finding appropriate solutions.

\section{- Doing honorary work ${ }^{15}$}

Doing honorary work represents the first form of participation by the residents of the town or region in the work of the foundation itself. Unlike societies, church 
and other beneficial organisations, the focus is more broadly defined in the community foundation. Broadly defined areas of operation offer options for diverse interests of the founders, donors and honorary workers.

Therefore, the urban community foundation of Gütersloh has various boards in which the residents of this town are represented: board of trustees, specialist council, public relations subcommittee, fundraising subcommittee, management of individual projects, etc.

Regarding the honorary work, it needs to be noted that it is about the form that cannot completely substitute the work of the employees employed on a full-time basis. However, without such a type of work, especially at the very beginning, the foundation could not come to life. In the long run, it is desirable that professional and honorary activities are complementary.

\section{- Donor-advised funds ${ }^{16}$}

Community foundations offer the option to contribute the funds that are tied to a specific purpose. Thus, the subsequent (co)founder is able to request that his or her donation be managed in accordance with their instructions. And, of course, the latter must be in accordance with the initial objectives of the foundation laid down in the statute.

According to the words of Ms Nina Spallek (2000:428), it seems that after nearly ten years of operation, the community foundation of the town of Gütersloh has been fairly successful in achieving the foundation's objectives, i.e., enhancing the quality of life, overcoming social problems, support to civil involvement. The foundation has well-adapted to the local structures and peculiarities. Since the very outset, the foundation has attracted the residents' attention through big projects and planned work with the public. Through a large number of participants, cooperation of societies and other generally beneficial organisations, it has managed to attract a large number of residents as co-creators of individual activities. At the same time, it has thus achieved good recognizability and acceptance in the region itself.

\section{Discussion}

The number of foundations in Europe (Schlüter; Then, Walkenhorst, 2001; Trstenjak, 2003) and elsewhere in the world (Anheier; Toepler, 1998) has largely increased during the last few decades. Without any doubt, greater well-being, particularly in the economically richest countries, has contributed to this. However, other political circumstances, especially the system changes in Eastern and Central Europe (Pinter, 2001), have also had a certain impact. Last but not least, the latest trends in the shrinkage of the welfare state and delegating its so far existing tasks to the voluntary and private sectors can fill us with a sense of 
foreboding that the main prosperity for foundations may still lie ahead.

Community foundations as subtypes of foundations represent a relatively new phenomenon at least in Europe. But the experience both in the West and East is very promising (Sacks, 2004; Zimmer; Priller, 2004). The attractiveness of this concept is undeniable because it combines the features and good sides of both societies and foundations. At the same time, it seems that this organisational form is able to overcome the shortcomings of both of them (e.g., the lack of capital in societies, the exclusive volition of one single founder in a foundation, or too narrow area of work in both societies and foundations). The other advantages the concept offers must not be overlooked either. These are: creating options for civil social activities and voluntary work for a particular local environment.

In the age of globalization and intense international exchanges of all kinds, it is, of course, merely a matter of time when the first such foundations are established in Slovenia. The fact that this has not yet happened results most probably from the notorious Slovene development level in relation to other countries of Central and Eastern Europe. At least it seemed so a few years ago. This caused that some foreign non-governmental organisations (in Slovenia, the most important NGO was certainly the Open Society Institute whose founder is Mr Soros, the wellknown philanthropist of the Hungarian descent) as well as other major foundations (e.g., the Ford Foundation) left Slovenia earlier than they did other countries of this part of Europe. It is obvious that some right incentives were lacking for the creation of this type of organizations in our country because the first community foundations appeared at the initiative of foreign foundations (Open Society Fund, Charles Stewart Mott Foundation) in Slovakia, Bulgaria, and in the Czech Republic.

However, some steps forward are expected even in Slovenia in this respect. Thus, Umanotera, the Slovenian Foundation for Sustainable Development (www.umanotera.org) within the framework of the Good Society programme ${ }^{17}$ (www.dobradruzba.org), which is funded by the Trust Fund for Civil Society in Central and Eastern Europe ${ }^{18}$ (www.ceetrust. org), is planning, inter alia, to establish some local funds ${ }^{19}$. The programme aims to improve the situation of the non-governmental organisations at the local level. For this purpose, Umanotera, along with partners, ${ }^{20}$ is preparing a study that will be presented at the national conference in 2005 . Then there will be invitation for applications to select eight to ten potential local funds or organisations that could establish such funds.

For the local communities and non-governmental organisations in Slovenia, this kind of development would offer plenty of opportunities: the emergence of such foundations could signify a fresh wind (and money) to start different projects at the local level, particularly in the less-developed regions of our country. And on the other hand, such foundations would represent an alternative resource for 
funding the work of the existing organisations, allowing them to achieve greater independence from the state resources.

According to the data from the the Ministry of the Interior (www.mnz.si), there are currently 153 foundations recorded in Slovenia as at 4 February 2005. Already a cursory glance can reveal that the majority of foundations are located in the capital, which certainly does not contribute to the balanced regional development advocated for in various documents. ${ }^{21}$ Therefore, the community foundation model represents a major opportunity for the development of the local communities throughout Slovenia.

\section{Conclusion}

The purpose of this short paper is to present the fundamental characteristics of the community foundations. The subject matter itself is, of course, too broad for a more detailed presentation. However, the interested reader can find further information in the list of literature or at web addresses.

Although community foundations have a nearly hundred-year-old tradition in the U.S. and Canada, they are a relatively new phenomenon in Europe. The favourable foreign experience from Western Europe (especially from Great Britain and Germany) as well as from Eastern Europe (Hungary, the Czech Republic, Slovakia, Poland and Bulgaria) speaks in favour of establishing community foundations also in Slovenia.

Therefore, the Umanotera project should be welcomed for the establishment of local funds. We can hope that these first examples serve as a good model for further development.

On the basis of favourable foreign experience, it can be justified to maintain that the community foundations are predestined to find solutions to social problems in a given town or region, and that they are translated into practice. 


\section{Notes}

${ }^{1}$ In English law, trust represents one of the relevant forms related to the asset management. It is basically about a special contractual relationship between the settlor and the trustee. The latter is required to manage the trust assets for the benefit of beneficiaries for a certain purpose. Trust has no juristic personality. It can be best compared with the dependent institution (for more details, see Trstenjak, 2003:79).

${ }^{2}$ In the US, the community foundations, which, according to the Anglo-American law, belong to public charities (the word "charity is used to denote all the forms of activities for beneficial purposes) enjoy greater tax benefits (tax relief, tax exemption, state supervision is less strict) than the private foundations.

${ }^{3}$ In the world there are various models of funding the non-governmental sector. In this regard, Great Britain and the USA stand out by having predominantly private resources. (See also Kolarič; Črnak-Meglič, 2002).

4 In Europe, the first community foundation was established by Open Society Foundations in Banska Bystrica in 1994 (Sacks, 2004).

5 They are: Initiative Bürgerstiftungen (www.buergerstiftungen.de), Arbeitskreis Bürgerstiftungen (www.die-deutschen-buergerstiftungen.de) Aktive Bürgerschaft e.V. (www.aktive-buergerschaft.de), Amadeo-Antonio-Stiftung (www.amadeo-antonio-stiftung.de) and Netzwerk Stiftungsgründung (www.wilabonn.de).

${ }^{6}$ It needs to be mentioned that these characteristics do not refer only to the foundations in Germany, but also to those in other countries where this concept has come to life.

${ }^{7}$ Plato is supposed to have left a certain fund to the Academy named after him. In his precisely determined last will and testament, Epicure had left his assets to his school which was in operation for 600 years after his death (Smith; Borgmann, 2001).

8 The Draft of the European Foundation Act also uses this division (Trstenjak, 2004).

9 Relating to this, Salamon and Toepler say (2000:5) that a decisive advantage of nongovernmental organisations over economic entities is that the former propose nondistribution constraint (organisations are prohibited from distributing any profit to their members). Another important advantage the non-governmental organisations can gain and thereby enhancing their credibility is that they must operate as transparently as possible (e.g., publication of the annual financial report on the website, etc.).

10 Alexandra Schmied describes (ideally and by types) 10 steps in establishing a community foundation. 1. Step one consists of a project feasibility study for establishing a community foundation in a town or region. 2. Step two refers to the decision to establish the community foundation: prior to the establishment, objectives or motivation for the establishment of the founders should be ascertained. It also needs to be clarified whether the community foundation is an appropriate form for the realization of an established interest or whether it might be easier to realize it in some other form (e.g., society). 3. In step three, according to the recommendations of Alexandra Schmied, it is appropriate to create a small and homogeneous initiative group that will draw up the objectives and the statute of the foundation. At this stage, there is also the recruitment of new, additional founders. The founders bind themselves in writing to contribute a certain amount of money for the establishment of the foundation. 4. In step four, the statute text is finalized in cooperation with the competent bodies and tax office. 5. In step five, the founders appoint the first members of the management and take a decision on the purpuse of establishing the community foundation (in German: Stiftungsgeschäft). 6. Step six refers to the presentation of individual legal bases (decision on the establishment purpose, statute, certificate of assets) to the competent state body. 7. In step seven, the state body issues a certificate on the foundation establishment. Then in step eight the foundation management requests the competent body to issue a certificater of representation (in German: Vertretungsbescheinigung) which enables the foundation to open a bank account 
to which the initial capital will be transferred. 9. In step nine, the founders are obliged to transfer the promised assets to the foundation after the legal person's status has been recognised. 10. In step ten, the foundation management submits a proposal for the recognition of the generally beneficial activity status (according to Schmied, 2004:467).

${ }^{11}$ State control is needed because there are no other internal supervisory bodies. The Slovene Foundations Act (Official Journal, No. 60/95) provides only management as an obligatory body of the foundation.

${ }^{12}$ There are also some other appropriate forms abroad. However, the Slovene legislation is not familiar with them (e.g., a private fund).

${ }^{13}$ The community foundation of the town of Gütersloh compiled a catalogue of criteria for the projects that are supported by it (those based on voluntary work, those that can serve as a model for similar projects, and projects that have a synergy effect). From the outset, these criteria ensure transparency and prevent a poor mood of unsuccessful applicants to various calls for tenders. The foundation does not support the projects from which only indivduals reap benefits (e.g., private persons, scholarships). It also rejects the projects with commercial objectives (e.g., entertainment, concerts, etc.). The project from Gütersloh, which belongs to this category, is called "Sport statt Zoff" (sport instead of strife). Within the framework of this project, the society for social pedagogy and psychomotor development takes care of the socially disadvantaged, restless and other children who are at risk of addiction. The children can devote their time to sport rather than to the street. For that purpose, children are offered exercise equipment several times a week, they participate in group games, and they discuss their experience with their attendants.

${ }^{14}$ An example from this category is that from the health care field. It is called "Kompetente Beratung in Sachen Gesundheit: Das Modellprojekt BIGS" (competent counselling regarding health: model project BIGS). The project's acronym stands for Bürgerinformation (information for residents), Gesundheit (health) and Selbsthilfekontaktstelle (contact branch for self-help). It is basically about an independent advisory service, the first of its kind in Germany, that deals with the issues linked to health, self-help, care. The informative offer is not intended to be an alternative to medical help, but it is designed to help people to orient themselves in a complex system of health care so that they are able to utilize the offer at the local and national levels. BIGS arose at the initiative of the urban community foundation. The occasion itself represented a request for financial support from the local hospital. Tthe foundation invited all the players in the health sector to participate in the roundtable discussion. The project was funded by the takings in the bingo organised by the community foundation, by the contributions given by the local bodies. Part of resources were contributed by the health insurance company of the town of Gütersloh. The town library provided a room (free of charge) for councelling purposes.

15 Since 1998, the community foundation of the town Gütersloh has been organising concerts in hospitals, in town and in the neighbourhood every three months. Thus, it changes the uniformity in hospitals. But on the other hand, young musicians and singers get the opportunity to perform for the audience and to acquire some experience. The project is independently organised by the foundation's board of trustees. The musicians do not get paid. This project is a good example how great effects can be achieved by voluntary involvement and by modest funding.

16 The last form of cooperation refers to the donations tied to a specific purpose. In such a case, the community foundation acts as a trustee of a certain donation designed for the precisely determined purpose in accordance with the foundation's statute. For this purpose, a subfoundation is established. It is not an independent legal person. In the community foundation of the town Gütersloh there is an example that falls into this column. The special subfoundation is named after its main founder. The purpose of its operation is to support 
youth culture (Wössner-Jugendfond named after Dr. Markus Wössner). The first project of this subfoundation was to obtain the premises of the town's ancient water tower. They were reconstructed into the cultural centre for youth.

17 The Good Society programme is designed to improve the funding of non-governmental organisations by other players, such as the state (that is to say, by individuals, municipalities, and companies), which, of course, represents implementation of one of the fundamental principles of community foundations, i.e., the tendency to heterogeneous resources for operation.

${ }_{18}$ The fund was established to support the development of the civil society in Bulgaria, the Czech Republic, Hungary, Poland, Romania, Slovakia and Slovenia. The ultimate objective of the fund is to support the creation of the non-governmental sector so that it would be capable of long-term existence and development (see www.dobradruzba.org).

${ }^{19}$ Semantically speaking, »local funds« represent what was called above »local foundations«.

20 The partners in the project are: the Legal Information Centre for Non-governmental organisations (PIC), Centre for Information Service, Cooperation and Development of Nongovernmental Organisations (CNVOS), the Slovene Association for Mental Health (ŠENT), the Association of Slovene Foundations (ZSU), and the Centre for Non-profit Management (CNM).

21 In this area, the most relevant strategic documents and regulations are: The National Development Programme 2001-2006 (Ministry of the Economy, 2001, www.gov.si/arr/9razvoj/1dr3.html), which, among the development priority tasks, mentions strengthening the balanced regional development, the Regional Development Strategy of Slovenia (Agency of the RS for Regional Development, Ministry of the Economy, 2001, www.gov.si/arr/2regije/1r-2.html), and the Promotion of the Balanced Regional Development Act (Official Journal, Nos. 60/1999, 56/2003, 83/2003).

\section{References}

Anheier, H. K. \& Toepler, S. (1998) Private Funds, Public Purpose: Philantropic Foundations in International Perspective (New York: Kluwer Academic/Plenum Publishers).

Anheier, H. K. (2001) Foundations in Europe: A comparative perspective, Civil Society Working Paper 18, (London: Centre for Civil Society at the London School of Economics and Political Science).

Anheier, H. K. \& Apel, A. (2004): Stiftungen in der Bürgergesellschaft: Möglichkeiten und Grenzen, Beilage zur Wochen₹eitung Das Parlament, B14/2004.

Bertelsmann Stiftung (izd.) (2004): Handbuch Bürgerstiftungen - Ziele, Gründung, Aufbau, Projekte, Verlag Bertelsmann Stiftung, Gütersloh.

Bundesverband Deutscher Stiftungen (2000): Arbeitskreis Bürgerstiftungen - Merkmale einer Bürgerstiftung. Verabschiedet auf der 56. Jahrestagung, Mai 2000, Berlin.

Kolarič, Z. \& Črnak-Meglič, A. (2002) Zasebne neprofitno-volonterske organizacije v mednarodni perspektivi (Ljubljana: Fakulteta za družbene vede).

Maecenata Institut für Philantropie und Zivilgesellschaft (2005) Bürgerengagement und Zivilgesellschaft in Deutschland. Stand und Perspektiven. Humboldt Universität, Berlin.

Monroe, H. (2004) Vermögensaufbau von Bürgerstiftungen: das amreikanische Beispiel. In Bertelsmann Stiftung (izd.) (2004): Handbuch Bürgerstiftungen - Ziele, Gründung, Aufbau, Projekte, Verlag Bertelsmann Stiftung, Gütersloh.

Pinter, F. (2001): The Role of Foundations in the Transformation Process in Central and Eastern Europe, in Schlüter, A., Then, V. \& Walkenhorst, P. (2001): Foundations in Europe: Society, Management and Law, (London: The Directory of Social Change). 
Sachs, E. W. (2004):Geschischte, Entwicklung und Merkmale von Bürgerstiftungen im internationalen Vergleich, v Handbuch Bürgerstiftungen - Ziele, Gründung, Aufbau, Projekte (Gütersloh : Verlag Bertelsmann Stiftung).

Salamon, L. M. \& Toepler, S. (2000) The Influence of the Legal Environment on The Development of the Nonprofit Sector (Baltimore: Center for Civil Society Studies, John Hopkins University).

Schmied, A. (2004) Zehn Scbritte zur Gründung einer Bürgerstiftung: Ein Leitfaden. V Handbuch Bürgerstiftungen - Ziele, Gründung, Aufbau, Projekte (Gütersloh: Verlag Bertelsmann Stiftung).

Schlüter, A., Then, V. \& Walkenhorst, P. (2001) Foundations in Europe: Society, Management and Law (London: The Directory of Social Change).

Smith, J. A. \& Borgmann, K. (2001) Foundations in Europe: the Historical Context. V Foundations in Europe: Society, Management and Law (London: The Directory of Social Change).

Spallek, N. (2004) Wir für unsere Stadt - Projektarbeit und Partiripationsmöglichkeiten in der Stadt Stiftung Gütersloh, in Handbuch Bürgerstiftungen - Ziele, Gründung, Aufbau, Projekte (Gütersloh: Verlag Bertelsmann Stiftung).

Trstenjak, V. (1997) Ustanove $v$ sodobnem pravnem sistemu, Doktorska disertacija (Ljubljana: Gospodarski Vestnik).

Trstenjak, V. (2003) Pravne osebe.(Ljubljana: GV Založba).

Trstenjak, V. (2004) Evropska ustanova - še eno poenotenje v EU, Pravna praksa, 23(5), pp 1 4.

Walkenhorst, P. (2004) Bürgerstiftungen als neue Organisationsform zivilgesellschaftlichen Engagements, in Handbuch Bürgerstiftungen - Ziele, Gründung, Aufbau, Projekte (Gütersloh : Verlag Bertelsmann Stiftung).

Zimmer, A. \& Priler, E. (ed.) (2004) Future of Civil Society. Making Central European NonrofitOrganisations Work. (Wiesbaden: VS Verlag für Sozialwissenschaften) 